\title{
The Limits of Authenticity and the "Burden of Representation": Palestinian Theatre on the British Stage
}

Irene Fernandez Ramos

\section{CpenEdition} Journals

Electronic version

URL: https://journals.openedition.org/ces/4636

DOI: $10.4000 /$ ces.4636

ISSN: 2534-6695

Publisher

SEPC (Société d'études des pays du Commonwealth)

\section{Printed version}

Date of publication: 1 April 2017

Number of pages: 91-101

ISSN: 2270-0633

\section{Electronic reference}

Irene Fernandez Ramos, "The Limits of Authenticity and the "Burden of Representation": Palestinian Theatre on the British Stage", Commonwealth Essays and Studies [Online], 39.2 I 2017, Online since 03 April 2021, connection on 04 June 2021. URL: http://journals.openedition.org/ces/4636 ; DOI: https:// doi.org/10.4000/ces.4636

\section{(c) (i) $\ominus$}

Commonwealth Essays and Studies is licensed under a Licence Creative Commons Attribution - Pas d'Utilisation Commerciale - Pas de Modification 4.0 International. 


\section{The Limits of Authenticity and the "Burden of Representation": Palestinian Theatre on the British Stage}

This article explores the increasing number of Palestinian theatre productions and practitioners on the British scene. Through two case studies, it unravels different strategies adopted to cope with the "burden of representation" which stems from postcolonial power structures still present today. The new system of international funding for theatre promotes a predetermined notion of authenticity in the representation of Palestinian identity, which British-Palestinian collaborative theatre productions seek to deconstruct.

In the last fifteen years, there has been an increasing interest in promoting art and culture as part of broader development strategies. This new interest comes from the recognition of economic development as insufficient and of the need for the promotion of cultural projects. The funding of theatre production in Palestine is intimately linked with these dynamics, and foreign-funded theatre within development strategies in Palestine has had diverse and entangled consequences still-to-be analysed. On the one hand, this phenomenon has increased the possibilities for access to funding for Palestinian theatre groups and has created a more fluid environment of artistic cooperation and dialogue. These collaborations have fostered the creation of a unique Palestinian theatrical language shaped by multiple influences while at the same time, they have promoted the image of Palestinian theatre on the international scene, contributing to raising awareness of the current ongoing occupation of Palestine.

On the other hand, this new environment might have had a negative impact on theatre's autonomy, as foreign funding has made theatre groups largely dependent on external financing. This dependence not only affects the material conditions of theatre production, but also the narratives, dramaturgy and aesthetics of the plays, which are directed to represent a stable image of Palestinian identity. Palestinian practitioners often find themselves subject to audiences' and donors' expectations of an essentializing "authenticity" and the burden of representing a stable image of Palestine and of being Palestinian. This paper will look at the situation in the United Kingdom, where the presence of Palestinian topics, texts, practitioners and productions has become increasingly important in recent years.

There are certainly Palestinian theatre groups that operate outside the system of international funding and which are able to stay apart from the dynamics that will be described in this paper. These groups, along with other groups which manage to fund some of their activities autonomously, can establish different messages and narratives which challenge the essentializing discourses of post-colonial aid system. Yet, the present paper will analyse two plays that are the result of collaborations between British and Palestinian practitioners. Through this analysis I aim to uncover different approaches that Palestinian-British productions have adopted, and how they deal with the power dynamics that underlie the cultural logic of globalization. In this sense, theatre processes cannot be understood as self-contained areas; theatre events are influenced by numerous unmeasurable variables that differ between each theatre event. The process 
of meaning creation needs to be analysed taking into account the audience's process of "framing, reading, interpreting and experiencing" (Rozik 16).

I have chosen two productions that involved professionals from the UK and Palestine and were performed both in the UK and Palestine. Both productions are part of a broader scene within which Palestinian voices are increasingly being heard in the UK. I want to claim that engaged political theatre can provide a certain space to the immediacy of both performers and audience experience. The ephemeral character of the process of meaning creation that happens within the theatre space gives practitioners the possibility to articulate what Schonmann defines as a "counter-text" which calls upon the audience to take action (181). Audience's engagement is relevant for political theatre insofar as it allows the articulation of messages that challenge dominant discourses and can contribute to shape consciousness.

\section{Palestinian Theatre on the British Stage: The Burden of Representation}

Since the Oslo Accords (1993-1995), there has been a proliferation of foreign-funded theatre production in Palestine and an increasing number of collaborative projects between UK-based and Palestinian playwrights and theatres. ${ }^{1}$ This new development does not mean that the hardship over theatre production's conditions has been lessened. The historical lack of means, "of original texts, actors, rehearsal spaces and an infrastructure," (Nassar 16-7) has been worsened even further by the post-Oslo restrictions on movement. The military occupation and the Israeli neo-colonial rule have caused and reinforced the internal difficulties that Palestinian theatre practitioners have to face in their work. In addition, there is a lack of national institutions, which could provide stability in terms of funding to ensure a solid and lasting dramatic production.

Nevertheless, the proliferation of foreign-funded drama in Palestine in the last twenty years has increased the possibilities of access to funding and therefore, the possibility of having a more dynamic dramatic and artistic production. This shift reflects a more favourable approach to Palestinian arts in general, and Palestinian theatre in particular. The proliferation of internationally funded productions, workshops, and projects have contributed to both making Palestinian voices more audible in international circuits and fostering artistic collaboration between European and Palestinian practitioners. In the $\mathrm{UK}$, the increasing interest in Palestinian theatre derives from a shift in the genre of political drama, which now looks for a "single-issue drama" that aims at the emotional involvement of the audience (Bernard, Taking Sides 164). Instead of focusing on domestic issues, British contemporary political theatre tries to create strong reactions and to foster commitment by putting the Palestinian question on stage.

This shift has been materialized in two different ways; on the one hand, the increasing presence of Palestine in British theatre in plays like My Name is Rachel Corrie or Seven Jewish Children - which were both hosted by the Royal Court Theatre in London

1. Some examples of these collaborations are, for instance, Al-Rowwad and The Freedom Theatre's network of UK friends, which actively support both theatres. Besides, the Edinburgh Forest Fringe 2015 presented "Shakespeare's sisters", produced by Beit-Jala-based Al-Harah Theatre, in an event developed through a collaboration between Forest Fringe, London's Gate Theatre, and the playwright David Greig, with significant support from the A. M. Qattan Foundation and the British Council. Palestinian playwrights like Raeda Ghazaleh, Dalia Taha and Imad Farajin have participated in the Royal Court International Residency. Furthermore, the Globe Theatre performed "Hamlet" in Ramallah on October 2015 within its world tour. 
for their first performances. These plays are written in English by British playwrights but deal with the Palestinian issue in different ways. None of them presents testimony from Palestinians (Bernard, Taking Sides 167), but they speak to the British audience from an insider perspective. This trend represents a strong political statement about the increasing support to the Palestinian situation and the rising criticism against Israeli occupation.

On the other hand, there has been a proliferation of theatre projects in which British and Palestinian groups and practitioners have been brought together to engage in artistic collaborations. These cases form the focus of this article and they certainly reflect a renewed interest in, and an ongoing negotiation with, the colonial status of Palestine from the UK's position as a postcolonial power. The presence of Palestinian art on the former colonial power's theatre scene counters processes that would contribute to the othering of Palestinian narratives. In a supposedly postcolonial era, the repositioning of Palestinian narratives on British stages might have a positive impact in terms of increasing the visibility of the current colonial occupation of Palestine.

At the same time, the current system of international funding, which includes most of the collaborative artistic projects, still subdues theatre production to international donors' guidelines in order to have access to the funding that is paramount for the survival of the Palestinian theatre scene. In a double-edged process, international funding is fostering the possibilities to maintain an active theatre scene with a clear international scope, while at the same time the shadow of material, financial, and artistic dependence hangs over that theatre scene. Palestinian theatre's dependence on foreign funding permeates to a level beyond its material conditions and into the realm of the message and significance of the theatrical momentum.

Traditionally, as stated by Nassar, Palestinian theatre survived by borrowing and adapting "models, ideas, and methods from world drama, including Israeli theatre, in an ongoing process [...] of liberation and healing" (16-7). Many examples can be found of theatre production, especially by Palestinians with Israeli citizenship, in which $\mathrm{Pa}$ lestinian theatre production has been tightly connected to Israel and beyond. ${ }^{2}$ Nassar defines this process as "cultural hybridity," which refers to the creation of a more fluid cultural form, easily adaptable to the international scene. "Hybridity" is here positively defined as a subversive tool for colonial subjects, which can erase "any existentialist claims for the inherent authenticity or purity of cultures" (Bhabha 83-4). However, there has been a wide range of academic critical discourse that has problematized the use of the notion of "hybridity" in postcolonial studies; some representative works are "Notes on the "Post-Colonial"' by Shohat; "The Politics of Cultural" and "Foreign Asia / Foreign Shakespeare” by Bharucha; "Hybridity: Limits, Transformations, Prospects" by Prabhu and "Debating Cultural Hybridity" by Werbner and Modood.

Drawing upon this theoretical discourse, the definition of Palestinian theatre as hybrid is problematic not only because we cannot deny the relevance of the pleas for authenticity that are intrinsic to the history of Palestinian theatre and which are also part of a survival strategy, but also because it would overlook the current development of theatre production in Palestine. Palestinian theatre's development is marked by its inclusion as part of the system of international funding, on which Palestinian

2. For more information see "The Arab in Israeli Drama and Theatre" and "Palestinians and Israelis in the Theatre: A Special Issue of the Journal Contemporary Theatre Review” by Urian; Interview with Bushra Karaman by Daoud. 
practitioners depend, and that system encourages them to convey a sense of authenticity. Contemplating contemporary theatre production only as borrowing and adapting elements from international theatre would ignore the existing power dynamics that lie behind cultural production in Palestine. In this sense, the representation of Palestinian reality is influenced by postcolonial images of the "Other" and these images reproduce essentialist discourses about Palestinian identity.

In my opinion, the use of "hybridity" to define the current situation is inaccurate and risks to overlook the consequences of colonial domination "if not articulated in conjunction with questions of hegemony and neo-colonial power relations" (Shohat 109). The conditions of contemporary production are inserted into a system that fosters that kind of essentialist lines. In this sense, the new position of Palestinian theatre on the international stage transforms this historical process of hybridization into an even more fluid form, in which Palestinian theatrical language seeks both to be understood and to present the image of the Palestinian "Other" to international audiences.

The impact of the renewed interest in Palestinian theatre - and its increasing dependence on international funding - has a new influence on Palestinian theatre's message and representation of the self that distances itself from Nassar's idea of hybridity as a mix and positive exchange of theatre models. Palestinian playwright Dalia Taha, resident playwright at the Royal Court's International Residency between 2013 and 2015, defines this new process in an interview conducted by Stephen Moss for The Guardian: "It's always like this for artists or writers who come from places with conflicts and wars. People, especially in the West, have specific expectations. You expect us to make a political statement, to tell the story of our suffering" (Moss). Taha's critique of "the West" refers here to those countries, which actually fund and direct the narrative of Palestinian drama on the world stage, i.e., mainly European and North American countries.

Taha's statement is relevant because it points at a kind of cultural hierarchy that echoes colonial and post-colonial narratives which not only promote certain values in a perceived "civilising" mission in the Middle East (Hazou 140), but also support essentializing views of - in this case - Palestine. The expectations that she talks about Palestine might correspond to what Lo and Gilbert have described as "Western fascination with non-Western performing arts" (32). The external gaze that is contributing to making Palestine visible worldwide is, at the same time, contributing to recreating imbalanced power structures, inside which the position of Palestine is always determined by preestablished narratives.

The Palestinian subject is increasingly visible on the international stage, but that does not necessarily mean that his/her voice is more audible. In fact, the present paper questions the different mechanisms by which Palestinian theatre productions have made sure that their voices were heard in the past couple of years. In that sense, the presence of the Palestinian subject on stage sometimes complies with a certain narrative which "might fulfil our colonial fantasy of unwrapping the masked Other" (SchwartzDuPre and Scott 350). In this respect, the expectations that Dalia Taha mentioned refer to the "burden of representation" which compels Palestinian performance artists not only to represent a stable image of Palestinian identity, but also to introduce a certain Palestinian authentic self.

The "burden of representation" is on most occasions an unconscious imposition; most of the time there is an underlying interest in fostering theatre productions which 
"transcends particular cultures on behalf of a universality of the human condition" (Pavis 6) - as is the case in the production of Richard II by Ashtar Theatre. The idea behind most of the collaborative theatre projects is what Christopher B. Balme calls "syncretic theatrical experiments," (2) in which the stage is decolonized and any form of theatrical exoticism is avoided. These experiments have indeed had great advantages in terms of educational and artistic opportunities for artists and students with restricted mobility due to the Israeli occupation. However, the process of universalizing theatre might aim at representing some kind of universal human experience that would "transcend (and ultimately ignore) the realities of Palestinian life and struggle" (Hazou 146).

At the same time, this universalization does not take into account the power imbalance that is still at stake. In this sense, the theatrical representation of the Palestinian subject does not necessarily "retrieve the lost subaltern subject as a recovered authentic voice who can be made to speak once more out of the imposed silence of history, because that subject is only constituted through the positions that have been permitted" (Young 207). Therefore the burden of representation of a stable Palestinian identity, which complies with what Taha defined as "Western expectations," highlights the uneven power distribution on the international stage.

However, we must not infer that in the face of the power imbalance presented above theatre groups remain powerless and immobile; indeed, theatre production and reception are fluid, which allows practitioners to enunciate a language through which they convey a form of agency. Simultaneously, the "burden of representation" represents nothing but a metanarrative that can be challenged when it comes to the daily work of theatre practitioners, both Palestinians and their British counterparts. Both Richard II and The Siege involved professionals from various countries in their productions and who collectively contributed to the artistic process. Both plays illustrate different yet similar theatrical trends of British-Palestinian productions from two of the most important and politically engaged theatre groups in Palestine. Both have different positions on the Palestinian scene, but they share a clear political and social interest ${ }^{3}$ that is materialized through their different activities.

Both plays represent voices that are considered authoritative either due to the original text - Shakespeare's text in Richard II - or due to the use of interviews and real characters' testimonies in the devising of The Siege. Both plays were well received by audiences and critics, but neither could escape deep-rooted expectations of the portrayal of a certain narrative on stage. The following analysis aims at unravelling the symbolic meanings that are brought about by these collaborations. It questions the possibilities for theatre to go beyond power differentials and convey an "authentic" message "outside" existing structures of power.

\section{Richard II}

The London's Globe theatre celebrated in 2012 the "Globe to Globe Festival," part of the World Shakespeare Festival (WSF). The "Globe to Globe Festival" brought together 37 theatre groups from different parts of the world to perform Shakespeare's plays in London over six weeks. It had a significant impact and coverage in academic

3. Ashtar Theatre has organized five "International Theatre of the Oppressed Festivals", with the participation of local and international groups. Freedom Theatre has developed a consistent work on cultural resistance. 
and media circles due, partly, to its connection to the Olympic Games, which gave it even more international projection. The Ramallah-based group Ashtar Theatre performed Richard $\mathrm{II}^{4}$ which was directed by Irish director Conall Morrison and cast thirteen Palestinian actors and actresses, including Iman Aoun, artistic director of Ashtar Theatre. The relevance of this production lies in the strong significance of Shakespeare's authority in English literature and his role as a national symbol, while at the same time being the most performed playwright worldwide.

The play was performed in Arabic with English subtitles for the London audiences and, although advertised as being performed in Palestinian Arabic, it was in fact translated into modern classical Arabic by Palestinian poet Ghassan Zaqtan, which kept "the poetry of the sentences but not the heaviness of the old classical (Arabic) translation" (Aoun n.p.). Translating Shakespeare's drama, which has been recognized worldwide as an integral element of British national identity, is in itself an act that "subverts the authority of Shakespeare's text" (Bulman 7) by locating it in a postcolonial context thereby re-interpreting it.

In my opinion, translation grants a renewed room for aesthetical and semiotic manoeuvre in which, for instance, a stylized use of classical Arabic to re-narrate Richard II's story represents an empowering appropriation not only of a British national symbol but also of the underlying universal human dilemmas posed by the play. Therefore, we could say that the Globe theatre's efforts to explore new meanings that can only be achieved by translation can be inscribed in a broader interest to reach "new levels of intercultural understanding" (Hoeselaars x). This idea of an "intercultural understanding" through the adaptation and translation of Shakespeare needs to be seen from the point of view of Shakespeare's Anglo-centred symbolic authority. The Globe theatre's interest in achieving an intercultural theatre event lies on the overarching universality of Shakespeare.

As stated on the Festival's webpage, ${ }^{5}$ the organizers were looking for the "inspirational stories" of people working in difficult conditions. At the same time, Dominic Dromgoole and Tom Bird - Artistic and Festival Directors respectively - added in the description of the festival that Shakespeare's plays "have midwifed new theatre cultures, spread light and laughter, and helped nations, new and old, to define themselves" (3). This statement emphasizes the constitutional authority of Shakespeare who, as stated by Dobson, "was declared to rule world literature at the same time that Britannia was declared to rule the waves" (Dobson 7). There is therefore a structural background that locates Shakespeare in a canonical position, which allows the festival organizers to openly maintain the assumption of the Palestinian group's need for help "to define themselves" through Shakespeare.

On the other hand, the significance of a Palestinian translation of Shakespeare is different when performed in Palestine for a Palestinian audience than when presented to an audience at the London Globe - "a site dominated by concepts of Shakespearean authenticity and originality" ( $\mathrm{Ng} 429)$. In this sense, the audience's expectations in London were articulated in a two-way process in which the burden of the authenticity of

4. Ashtar Theatre has also co-produced "This Flesh is Mine" (2014) and "When Nobody Returns" (2016) with London-based theatre company Border Crossings and the Central School of Speech and Drama, with the support of the Arts Council England, British Council, Nour Festival and Rose Bruford College.

5. For more information see: http://globetoglobe.shakespearesglobe.com/archive/2012/ 
Shakespeare's texts clashed with the intercultural interests of the organization. The audience, more or less consciously, expects a certain level of authenticity in the Palestinian performance of Shakespeare, which should stay in tune with the "original." As stated by $\mathrm{Ng}$, the audience needed to locate an authentic point of reference, "a set of stable signs and significations" (429) to understand the performance; therefore, Shakespeare becomes a point of reference from which the performance is understood.

Back in 2012, Ashtar Theatre had to deal with a reception background highly influenced by the situation in many Arab countries where the so-called "Arab Spring" was challenging the long-established political systems. The political situation preceded the play's reception in a context in which organizers and audience expected a certain reflection of the political situation. Therefore, Ashtar had to cope with the tension between the intercultural aim of the festival organizers and the expectations of an inherent authenticity - either Palestinian or British. First of all, Ashtar assumed an anti-essentialist strategy by detaching their production from the actual Palestinian context. The Ramallah-based group created a version, which was not explicitly tied to the Palestinian political and/or social reality. As stated by Iman Aoun in an interview with Sarah Irving, "at some point you could see a Palestinian dress onstage [...], but it does not particularly say that this is happening here in Palestine [...]. We want the audience to concentrate and think".

Ashtar's de-contextualization of Richard II was a conscious move that uncovered broader themes that were present in Shakespeare's original text. As stated by Audebert, the text alone proposes a basic political message which is independent from the external context and the personal background (76). In this sense, the emphasis on a non-specific locality shifted the play's political resonance towards more general topics that would more easily connect with a London audience's political consciousness. Therefore, Ashtar Theatre managed to convey their own message and focus on a neat and simple representation of Shakespeare's themes: kingship and power struggles; and they successfully questioned the intricacies of the game of power and the seemingly unavoidable corruption of power, without falling into the trap of positioning themselves as voices of the authentic Palestinian experience.

At the same time, it could be argued that this delocalization and subsequent representation of broader topics might support the WTF organizers' interest in claiming the universality of Shakespeare's themes. However, Ashtar Theatre managed to treat Shakespeare "as neither 'universal' nor inherently allied with 'cultural imperialism" (Litvin, Walkling, and Cormack 5), and speak to different audiences. Shakespeare's undeniable relevance as a playwright was brought to the stage by Ashtar's theatre in a conventionalized and saliently artistic way, refusing to portray homogenized human experiences. Before the postcolonial dilemma that Shakespeare's translation posed within the WSF, Ashtar not only decided to avoid representing nationalist ideas of Palestine, they also enabled a more complex discussion about the overarching topics of the play.

\section{The Siege}

The Siege was produced by Jenin-based Freedom Theatre in 2015 and co-directed by Nabil Al-Raee from Palestine and Zoe Lafferty from the UK. The story is based on the 2002 events in the Church of the Nativity in Bethlehem, in which the Israeli Defence Force (IDF) occupied Bethlehem as part of Operation Defensive Shield. As a result, 
thirteen Palestinian fighters fled into the Nativity Church - a UNESCO World Heritage site and one of the most sacred Christian sites in the world - where they sheltered with around 200 monks and civilians. ${ }^{6}$ More than a decade later, the Freedom theatre traced the fighters, who now live exiled across Europe and Gaza, and collected their personal stories and memories.

The play was premiered in Jenin and was presented in ten different locations around the UK during the spring of 2015. The Freedom Theatre's UK Tour was the largest tour undertaken by a Palestinian theatre company in the UK (Hutchison) and was funded by the British Council, The Arab British Centre and the Arts Council England, among others. The play presents six men during the 39 days of siege inside of the church and exposes their deepest fears and contradictions. It uses video footage - showing, for instance, fragments from the Israeli invasion of Bethlehem -, excerpts from interviews with the fighters themselves, adds the meta-reflexive presence of a tour guide, interpreted by Ahmed Tobasi, and emotionally charged and disquieting fighting scenes.

The Siege uses the techniques of documentary theatre to represent Palestinian voices on stage - which is, in fact, not a new trend in the Palestinian-Israeli theatre scene by inserting real testimonies into a dramatic work. Freedom Theatre draws upon this archive, while at the same time offering an interpretation and critique of its different political implications. Thus, the Palestinian narrative is unapologetically located at the centre of the stage, arguing against the need to "balance' their stories with the Israeli point of view" (Bernard, Taking Sides 172).

The presence of this production on British stages says a lot about the recent development not only of the representation of Palestinian on the British stage, but also of a new openness to collaborative projects that challenge prejudices about Palestine. At the same time, this development is still not free from controversy and the representation of the voices of Palestinian fighters were strongly criticized in some British media. Controversy sparked when the right-wing Daily Mail published an article on 2 May 2015 defining The Siege as "a play sympathising with Palestinian terrorist groups" (Craven). By portraying the Freedom Theatre as a terrorist sympathiser, the journalist reproduces the orientalist principle enunciated by Edward Said, according to which: "there are good Arabs (the ones who do as they are told) and bad Arabs (who do not, and are therefore 'terrorists')" (Said 306). This reductionist premise by tabloids diminishes the Freedom Theatre's work and ultimately seeks to silence Palestinian voices.

Similarly to Richard II, The Siege signalled the core values that underlie the characters' decisions without trying to essentialize any kind of authentic experience. However, Ashtar conveyed its message through Shakespeare's language, articulating a universality that the WSF organizers were keen to promote. The Freedom Theatre, on the other hand, combines fragments of the characters' real interviews while placing their experiences at the centre of the stage, showing their dilemmas and internal struggles.

The Siege invites questions to be raised regarding the polarised division between "good Arabs and "bad Arab" that, as stated by Sanz Sabido, has characterized British media for long time (205). In this sense, the play offers an historical account that differs from traditional media account and reinvests the symbolism of the figure of the fighter. In this sense, just as Ashtar Theatre disregarded London audiences' expectations 
and adapted Shakespeare's Richard II to a placeless yet meaningful context, the Freedom Theatre responded by threatening the stability of the figure of fighter itself and by giving voice to unheard experiences and testimonies whose authority could not be questioned.

\section{Concluding Remarks}

This article has examined two different theatrical approaches present in collaborations between Palestinian and UK based practitioners. Both projects were performed on British and Palestinian stages and therefore exposed to both British and Palestinian audiences. The collaboration aimed at reaching different audiences beyond Europe and those involved wanted to assert their creative agency by challenging any biased assumption of what Palestinian theatre should look like. As mentioned above, even though theatre production is included and influenced by a metanarrative, the agency of practitioners is undeniably essential for the construction of meaning.

Both Richard II and The Siege have strong political meanings that found their ways onto the stage and to the audiences. Of course, the two plays do not represent the whole Palestinian-British scene; moreover, the present paper's interest lies in presenting the particular junctures in which the burden of political representation meets with aesthetic considerations. Theatre helps to counter media representations and stereotypes and shows a new approach to the Palestinian question within the UK. The two analysed plays adopted two different strategies: Richard II is deterritorialised from Palestine and The Siege puts the focus on usually unheard voices. Ultimately, both experiences transcend the "burden of representation" of a stable self that would comply with the audience's views and articulate transformative discourses.

In this sense, this paper has highlighted the need for a critical approach that does not disregard the relevance of power dynamics within international theatre collaborations. At the same time, I wanted to both recognize and emphasize the actual potential of theatre to foster reflection and concede an important space for the audiences in the UK and Palestine to interact with the performers and recreate different meanings. Likewise, as stated before, the daily work of both British and Palestinian practitioners distances itself from any pre-established idea of what Palestinian experience is and this is something that then gets translated into the performance and its interaction with the audience.

Finally, and most importantly, the presence of Palestinian voices on a British stage is in itself a political statement, especially because, as we saw, the way to get there is not at all free from difficulties. For instance, in Richard II, Henri Bolingbroke announces his trip to Jerusalem to clean his bloody hands after killing King Richard II. The London audience laughed at the reference. Later on, in a special discussion with Iman Aoun, the company's artistic director, and other members of Ashtar Theatre entitled "Theatre under Occupation: What does Shakespeare have to say to the Palestinians?"7 Nicola Zreineh, the actor interpreting Bolingbroke in Richard II, spotted the irony of not being able, as a Palestinian living in Bethlehem, to visit Jerusalem while his character, five centuries ago, could travel over 2000 miles from London to Jerusalem (West n.p.).

\footnotetext{
7. The discussion is recorded and available online: http://inminds.com/article.php?id=10544
} 
The recent upsurge in productions like the ones we have analysed in the present paper are extremely important to balance misunderstanding and misrepresentation of 67 years of occupation and conflict. The representation of Palestine has traditionally reflected power inequalities and sharpened the division "us vs. them"; in this sense, theatre can help audiences to "imagine a kind of political belief and political belonging that is seemingly more consequential, urgent and 'real' than their own political circumstances" (Bernard, Consuming Palestine 201). At the same time, as we have seen, power imbalance may be translated on stage via a renovated "burden of representation" that can only be deconstructed by means of an open and frank dialogue about the Palestinian question in the UK, overcoming the colonial heritage and examining its postcolonial role. The two cases presented in this paper represent good examples of different theatrical strategies to present Palestinian voices on stage while overcoming that burden.

Irene Fernandez Ramos SOAS, University of London (United Kingdom)

\section{Works Cited}

Aoun, Iman. "Shakespeare in Palestine: Theater Director Speaks on Arabic Version of Richard II Interview by Sarah Irving." Electronic Intifada. 27 Apr. 2012. Accessed 30 Dec. 2016 <https:// electronicintifada.net/content/shakespeare-palestine-theater-director-speaks-arabic-versionrichard-ii/11218>.

Audebert, C. F. "Choice and Responsibility in 'Rijāl Fī Al-Shams." Journal of Arabic Literature 15 (1984): 76-93.

Balme, Christopher B. Decolonizing the Stage: Theatrical Syncretism and Post-Colonial Drama. Oxford: Clarendon P, 1999.

Bernard, Anna. "Consuming Palestine: The Israeli-Palestinian Conflict in Metropolitan Popular Culture.” Journal for Cultural Research 16.2-3 (2012): 197-216.

—. "Taking Sides: Palestinian Advocacy and Metropolitan Theatre." Journal of Postcolonial Writing 50.2 (2014): 163-75.

Bнавна, Homi K. The Location of Culture. New York: Routledge, 1994.

Bharucha, Rustom. The Politics of Cultural Practice: Thinking through Theatre in an Age of Globalization. Hanover: Wesleyan UP, 2000.

—. "Foreign Asia / Foreign Shakespeare: Dissenting Notes on New Asian Interculturality, Postcoloniality, and Recolonization." Theatre Journal 56.1 (2004): 1-28.

BIRD, Tom, and Dominic Dromgoole. Globe to Globe. 37 Plays, 37 Languages. Shakespeare's Coming Home. Accessed 1 Jun. 2017 <http://www.shakespearesglobe.com/uploads/ffiles/2011/10/326025. pdf $>$

Bulman, James C. "Introduction: Shakespeare and Performance Theory." Shakespeare, Theory, and Performance. Ed. James C. Bulman. London: Routledge, 1996. 1-11.

Craven, Nick. "UK Taxpayers Fund 'pro-Terrorist' Play: $f, 15,000$ of Public Money Given to Show Based on the Words of Hamas Killers." The Daily Mail. 3 May 2015. Accessed 30 Dec. 2016 <http://www.dailymail.co.uk/news/article-3065771/UK-taxpayers-fund-pro-terrorist-play-15000-public-money-given-based-words-Hamas-killers.html>.

DaOud, Siham. "Interview with Bushra Karaman." Contemporary Theatre Review 3.2 (1995): 113-21.

Dobson, Michael. The Making of the National Poet: Shakespeare, Adaptation and Authorship, 1660-1769. Oxford: Clarendon P, 1992.

Hazou, Rand T. "Dreaming of Shakespeare in Palestine." RIDE: The Journal of Applied Theatre and Performance 20.2 (2015): 139-54.

Hoeselaars, Ton. "Preface." Shakespeare and the Language of Translation, Ed. Ton Hoeselaars. London: Bloomsbury Methuen Drama, 2012. ix-x.

Hutchison, David. "Battersea Arts Centre Unveils Year-Long Plan to Highlight the 'Breadth and Depth' of UK Theatre." The Stage. 23 Jan. 2015. Accessed 30 Dec. 2016 < https://www.thestage. co.uk/news/2015/battersea-arts-centre-unveils-year-long-plan-highlight-breadth-depth-uktheatre $/>$. 
Litvin, Margaret, Saffron WALking, and Raphael cormack. "Full of Noises: When 'World Shakespeare' Met the "Arab Spring."' Shakespeare 0.0 (2015): 1-16.

Lo, Jacqueline, and Helen GILBERT. "Toward a Topography of Cross-Cultural Theatre Praxis." TDR/ The Drama Review 46.3 (2002): 31-53.

Moss, Stephen. "Palestinian Playwright Dalia Taha: 'You Want Stories of Suffering'." The Guardian. 22 Feb. 2015 <http://www.theguardian.com/stage/2015/feb/22/dalia-taha-fireworks-interview>.

Nassar, Hala Khamis. "Stories from under Occupation: Performing the Palestinian Experience." Theatre Journal 58.1 (2006): 15-37.

NG, Eleine. "Performing Shakespeares: (Dis)locating the Authentic in a Korean Intercultural Dream." Shakespeare 10.4 (2014): 428-42.

Pavis, Patrice. The Intercultural Performance Reader. Oxon: Routledge, 1996.

PrabHu, Anjali. Hybridity: Limits, Transformations, Prospects. Albany, NY: SUNY P, 2007.

RozIK, Eli. Generating Theatre Meaning: A Theory and Methodology of Performance Analysis. Sussex: SAP, 2010.

SAnz SABIDO, Ruth. "Palestine in the British Press: A Postcolonial Critical Discourse Analysis." Journal of Arab \& Muslim Media Research 8.3 (2015): 199-216.

SAID, Edward W. Orientalism. 1978. New York: Vintage, 1979.

Schonmann, Shifra. "Between Text and Counter-Text: Theatre in Search of Political Meaning." Palestinians and Israelis in the Theatre: A Special Issue of the Journal Contemporary Theatre Review. Contemporary Theatre Review 3.2 (1995): 175-83

SchwARtz-Dupree, Rae Lynn, and Shelby scotт. "Postcolonial Globalized Communication and Rapping the Kufiyya." Communication, Culture \& Critique 8.3 (2015): 335-55.

SHOHAT, Ella. "Notes on the 'Post-Colonial"' Social Text 31-32 (1992): 99-113.

Urian, Dan. "Palestinians and Israelis in the Theatre: A Special Issue of the Journal Contemporary Theatre Review" Contemporary Theatre Review 3.2 (1995): 1-227.

- The Arab in Israeli Drama and Theatre. Amsterdam: Harwood Academic, 1997.

Werbner, Pnina, and Tariq Modood. Debating Cultural Hybridity: Multicultural Identities and the Politics of Anti-Racism. 1997. London: Zed Books, 2015.

West, Samuel. "Richard II, by Actor \& Director Samuel West”. Shakespeare's Globe Blog. 5 May 2012. Accessed 30 Dec. 2016 <http://shakespearesblog.webstarsltd.com/richard-ii-by-actor-samwest/>.

Young, Robert. White Mythologies: Writing History and the West. London: Psychology P, 2004. 